\title{
SCIENCE PREPARATION OF FUTURE PSYCHOLOGISTS IN HIGHER EDUCATION INSTITUTIONS: COMPARATIVE ANALYSIS OF SPANISH AND UKRAINIAN EXPERIENCE
}

\author{
Valentyna Bilyk \\ Candidate of Pedagogical Sciences, \\ National Pedagogical Dragomanov \\ University, Kyiv
}

DOI: https://doi.org/10.31435/rsglobal_wos/31012019/6317

\section{ARTICLE INFO}

Received: 08 November 2018

Accepted: 25 January 2019

Published: 31 January 2019

\section{KEYWORDS}

science preparation, foreign experience, national experience, directions of modernization, future psychologists.

\begin{abstract}
Reforming Ukrainian educational system in the context of leading tendencies in European educational space development points to the importance of studying advanced ideas of future psychologists science preparation in higher education institutions in the developed countries. Comparison and analysis of foreign and national pedagogical experience in implementation of science education of future psychologists will contribute to solving the problems of its modernization in national higher education institutions. According to the above tasks, we held a comparative analysis of science preparation of future psychologists in leading institutions of higher education in Spain and Ukraine and pointed out its features. It is noted that the representative differences of science education in Spain from such in Ukraine is its professional orientation, integrity and significant advantage in the amount of credit and content filling. With the help of theoretical, empirical and statistical methods, recommendations on modernization of future psychologists science preparation in national higher education institutions were developed, according to which modernization of science preparation of future psychologists in national higher education institutions is expedient in the direction of: increasing the number of science disciplines, science preparation and hours / credits for their study, realization of the process of science preparation integration in the content of professional oriented disciplines, implementation of innovative teaching methods, leading scientific theories and studying the best practices of developed countries (holding international symposia, conferences, training, etc.). Presented research provides basis for scientific development of pedagogical conditions for realization in national higher education institutions, implementation of identified leading ideas of science education in Spain, and suggests the necessity to find ways to apply the proposed recommendations regarding the modernization of the science education of future psychologists.
\end{abstract}

Citation: Valentyna Bilyk. (2019) Science Preparation of Future Psychologists in Higher Education Institutions: Comparative Analysis of Spanish and Ukrainian Experience. International Academy Journal Web of Scholar. 1(31), Vol.2. doi: 10.31435/rsglobal_wos/31012019/6317

Copyright: (C) 2019 Valentyna Bilyk. This is an open-access article distributed under the terms of the Creative Commons Attribution License (CC BY). The use, distribution or reproduction in other forums is permitted, provided the original author(s) or licensor are credited and that the original publication in this journal is cited, in accordance with accepted academic practice. No use, distribution or reproduction is permitted which does not comply with these terms.

Introduction. Reforming of Ukrainian educational system in the context of leading tendencies in European educational space development predetermines importance of studying the advanced ideas of science preparation of future psychologists in higher education institutions in developed countries of the world. In the period of active reforms, comparative-pedagogical researches have not only theoretical but also practical value. We believe that it is comparison and analysis of foreign and 
national pedagogical experience in the implementation of science preparation of future psychologists will contribute to solving the problems of its modernization in national higher education institutions.

Analysis of the latest research and publications shows that national scientists are trying to get as much information as possible about their foreign colleagues work from outlined issues and integrate their experience in national education system.

In the opinion of V. G. Kremen, before modern higher pedagogical education, there is a rather difficult task: "to preserve all positive achievements and experience of Ukrainian education and to enrich it with innovative achievements of European educational environments, to harmonize them with Ukrainian" [4, p. 31].

F. G. Vaschuk agrees with this idea, and supporting the idea of constructing education in European traditions, believes that "reforming higher education can only be successful if national education does not lose its achievements, but organically fits into European integration preferences" [2, p. 43]. In defining the goal of higher education in Ukraine modernizing, scientist emphasizes the need to create such a model of educational process, in which the best national and foreign traditions would be optimally combined" [2, p. 43].

Analysis of o science preparation of future specialists state, including future psychologists in different countries of the world, has shown that both foreign and domestic scientists insist on its significance and necessity for modernization in the system of higher education. Thus, foreign scholars (E. Audisio, R. Scaglia, M. Terradez, etc.), stating the presence of low level of science preparation of future psychologists, argue that the reason for this situation is lack of motivation for students to study sciences. This, according to E. Audisio, is due to lack of relationship between science education and professional activity [6, p. 101]. Solution to the above-mentioned range of problems, M. Terradez, R. Scaglia and E. Audisio, see integration of the science and professional preparation of future psychologists [8, p. 227].

A. B. Konobeyeva argues that science education cannot remain in the state of internal isolation and self-sufficiency, it should be closely linked to the processes of educational reforms [3, p. 112113]. In the opinion of A. B. Konobeyeva, reorganization of science education, taking into account main ideas of education modernization (quality, efficiency and accessibility), suggests, along with updating its contents and methodological basis, fruitful cooperation of science teachers, humanities and pedagogical disciplines, orientation of educational process to the integral vocational training, formation of the student's professional skills and abilities, knowledge about main trends in science formation abroad and usage of the most valuable world experience in realization of science preparation in higher educational establishments [3, p. 112-113].

Taking into account the above mentioned, we consider it expedient to investigate peculiarities of science preparation of future psychologists in higher education institutions of the developed countries.

Aim and tasks. Purpose of the article: on the basis of leading ideas of science education in Spain, to outline ways of modernization of future psychologists scientific preparation in national higher education institutions.

Objectives of the study: 1) to conduct a comparative analysis of science preparation of future psychologists in leading higher education institutions of Spain and Ukraine and to highlight their peculiarities; 2) to develop recommendations for modernization the directions of science preparation of future psychologists in national higher education institutions.

Research methods. We believe that one of the crucial stages of scientific research is the choice of methods for its implementation. By choosing research methods, we first of all evaluated the degree of their necessity, objectivity, reliability and validity. Therefore, in accordance with the above problem we used a set of methods, namely: theoretical: analysis of scientific and scientific-methodical literature - in order to determine the state of the problem under study; comparative analysis, comparison and generalization - to systematize research results, formulate conclusions and identify areas for further research. Empirical part of the study was conducted using our specially designed questionnaires for university students and professors. In order to analyze the data of experimental research and substantiation the probability of obtained results, statistical methods were used: mathematical calculation of pedagogical experiment results, qualitative pedagogical analysis of quantitative statistical parameters.

Research Results and Their Discussion. In conditions of national education adaptation to the requirements of European educational space and in accordance with the Law of Ukraine "On Education" regarding the necessity of finding and implementing the latest approaches to ensuring a qualitatively new level of future specialists preparation on the basis of preserving national treasures and using the best examples of world experience, we believe that study of realization experience of science preparation of future psychologists in higher education institutions in the developed countries of the world, will open new opportunities for its modernization in higher education institutions of Ukraine. 
Significant scientific interest to the outlined problem, in our opinion, is the progressive achievements of education in Spain, which demonstrates high level of psychologist's preparation, in accordance with world standards [7].

For a more detailed comparison of future psychologists science preparation state, we have analyzed corresponding curriculum of the Autonomous University of Madrid (Universidad Autónoma de Madrid (UAM)) - Spain, University of Granada (Universidad de Granada (UGR)) - Spain, University of Malagasy (Universidad de Málaga) - Spain, National Pedagogical Dragomanov University (Ukraine), Zhytomyr State University. Ivan Franko (Ukraine) and the National University of Ostroh Academy (Ukraine).

Analysis of the content of disciplines provided by curriculum of psychologists preparation at Autonomous University of Madrid showed that science preparation of future psychologists at the university is realized both through the study of special science disciplines: "Neurofiziología y conducta (Neurophysiology and Behavior)", 6 credits at 1 and 2 courses, "Etología y neurofisiología de la comunicación y la cognición (Etology and Neurophysiology of Behavior and Cognition)", 6 credits, "Health Psychology (Health Psychology)", 6 credits, and through the study of integrative disciplines (themes of science disciplines integrated into the content of disciplines of professional direction) [9].

Detailed analysis of the work program on discipline "Farmacología de la conducta (Pharmacology for professional orientation)" led to selection of the modules of science-oriented direction in this course, namely: Module 1. "Principios de la neurotransmisión química (Principles of chemical neurotransmission)" and Module 2. "Receptors and enzymes como objetivos de la acción de los fármacos (Mechanisms of action of enzymes on receptors)", which confirms integration of science in the process of professional preparation. Developers of the curriculum for mastering the content of only specified modules provided 18 hours, including 6 hours of classroom (Horas presenciales) and 12 hours - independent students work (Horas no presenciales).

The "Psicología Ambiental (Psychology of the Environment)" program revealed a larger number of integrated science and content topics, namely: Aspectos conceptuales y metodológicos de la ecología (Conceptual and methodological aspects of ecology); Cognición ambiental: Concepts y teorías (Ecological Education: Theory and Practice); Estresores ambientales (Ecological stress-related factors); Factors of relevance and comportamiento: Efecto del ambiente acústico. Efectos del medio ambiente térmico. Efectos del medio ambiente luminoso (Physical factors and behavior: effects of acoustic thermal and irradiating media); Medio Natural y Bienestar Humano. (Natural environment and human well-being). It was forseen 45 hours by study program, of which 16 and 29 hours of classroom and independent work, respectively.

It should be pointed out that topics "Desarrollo fisiológico del período de pubertad (Physiological development of puberty period)" from the selective discipline "Psicología de la Adolescencia y de la Juventud (Psychology of adolescence and youth)" and "Mecanismos biológicos del envejecimiento (Biological aging mechanisms )" from the selective discipline "Psicología de la vejez (Psychology of old)" age are included in the course "Age Physiology (Fisiología de la edad)", which relates to the disciplines of science cycle. For assimilation of the content of outlined themes, was provided for 15 hours respectively, of which 6 hours of classrooms and 9 hours of independent students work.

Having made the appropriate calculations, we have an opportunity to note that for implementation of science preparation of future psychologists at Autonomous University of Madrid there provides 678 hours, which is 27.12 credits (in Spain 1 ECTS credit $=25$ hours), or $11.3 \%$ of the total hours / credits (pic. 1).

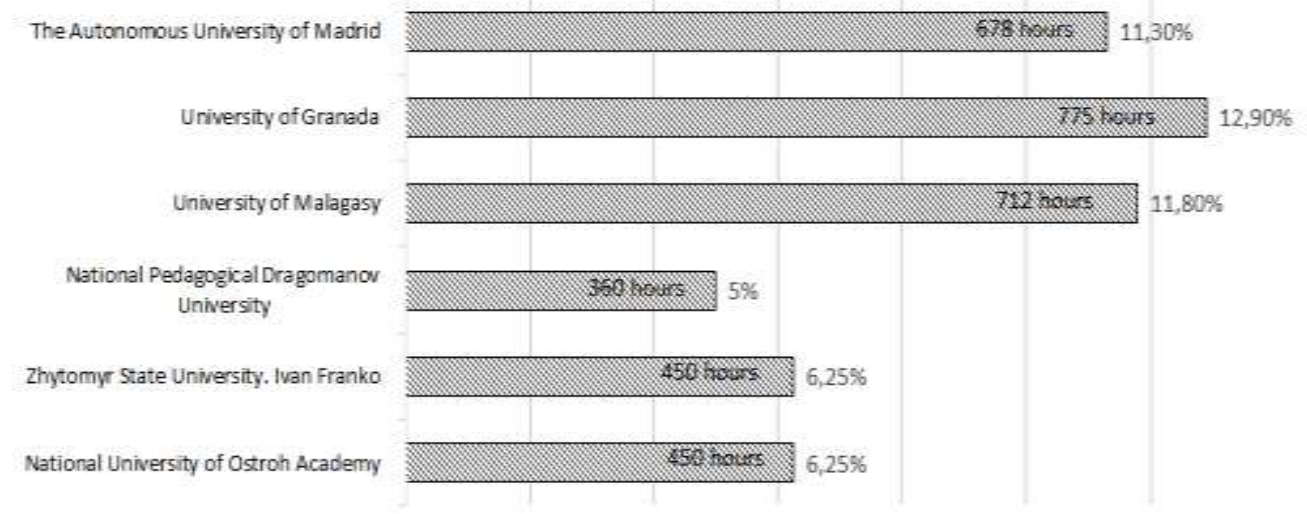

Fig. 1. Number of hours allocated for implementation of science preparation at the universities of Spain and Ukraine 
In order to improve quality of future specialists preparation at the University of Granada, which has been implemented since 1974, the curriculum has been changed three times. Currently, future psychologists are being trained according to the curriculum approved in 2003 [10]. Normative science preparation at University is determined by disciplines: on the first course - "Fundamentos de Psicobiología (Fundamentals of Psychobiology)" (6 credits), on the second year - "Psicología Fisiológica (Psychophysiology)" (6 credits) and on the third year - "Psicofisiología Clínica (Clinical Psychophysiology)" (6 credits), "Neuro Fisiológica (Neurophysiology)" (6 credits) and "Psicobiología del Desarrollo (Psycho-biology of Development)" (6 credits).

In the detailed analysis of training and working programs on the disciplines of professional orientation, we find in their content integrated themes of science namely: in the working programs of disciplines "Psicopatología Infantil y Juvenil (Psychology of children and adolescents)" (2 year) there is a theme: "Desarrollo fisiológico del Infantil y Juvenil (Physiological development of children and adolescents)", which is the subject of the study of age physiology and "Psicofarmacología (Psychopharmacology)" (4 year course); theme: Principios de la neurotransmisión química (Principles of chemical neurotransmission), which is the subject of studying cellular physiology. To study the outlined topics, it is allocated 12 hours, of which 4 hours for classroom and 8 hours for independent work.

Consequently, according to the curriculum for future psychologists preparation at University of Granada for implementation of science education there are 775 hours, or 31 credits, which is $12,9 \%$ of the total hours/credits.

Curriculum for future psychologists preparation at Malaga University is divided into several cycles. It is interesting to us that science is singled out as a separate cycle of "Módulo de Bases Biológicas de la Conducta (The module of biological principles of behavior)", the content of which is provided by disciplines "Biología (Biology)", "Fisiología (Physiology)", "Fundamentos de Psicobiología (Fundamental Psychobiology)", "Neuropsicología (Neuropsychology)", each of which is awarded for 6 credits, and integrated into the cycle "Módulo de Personalidad y Psicopatología (The module of personality and psychopathology)", where "Bases Biológicas de las Psicopatologías (Biological bases of psychopathology) " " (4,5 p redone) is studied [11].

Thus, 28,5 credits or 712,5 hours are provided for implementation of future psychologists science preparation at Malaga University, which is $11,8 \%$ of the total hours/credits.

Analysis of the curricula for future psychologists preparation in national higher education institutions points to the tendency of a significant reduction, both the number of academic disciplines that provide implementation of science preparation and the number of credits for their study. In particular, according to the curriculum for future psychologists preparation in the 2015-2016 academic year at National Pedagogical Dragomanov University, the normative part of science preparation cycle was implemented through the study of following disciplines "Safety of Life" (3 credits), "Ecology" (3 credits) and integrative discipline "Biology" (9 credits), which included modules: "Fundamentals of medical knowledge and protection of children" ( 3 credits), "Fundamentals of anatomy and physiology of the central nervous system" ( 3 credits) and "Age Physiology and Auliology" ( 3 credits). In addition, students were offered one of two courses for a choice "Pre-medical Emergency Care" (3 credits) or "General Biology with the Basics of Genetics" (3 credits).

In curriculum for future psychologists preparation from 2016-2017 academic year at National Pedagogical Dragomanov University in normative part of science preparation cycle there only two disciplines were noted, namely: "Safety of Life" (3 credits) and "Ecology" ( 3 credits). The list of selected disciplines was increased by presence of such disciplines as: "Fundamentals of medical knowledge and protection of children" ( 3 credits), "Age physiology and valeology" ( 3 credits), "Premedical emergency care" ( 3 credits), "General Biology with the Basics of Genetics" (3 credits). However, from this list, students could choose only two disciplines, which automatically reduced the total amount of loans for science preparation of future psychologists.

So, at National Pedagogical Dragomanov University term for implementation the science preparation of future psychologists has decreased from 18 credits (540 hours), which was 7,5\% of their total number to 12 (360 hours), which was $5 \%$ from their total quantities. It is $2,5 \%$ less than in the previous curriculum, and 6,3\% less than in Autonomous University of Madrid, 6,8\%, less than at Malaga University, and 7,9\% less than at University of Granada.

Analysis of curriculum for future psychologists preparation at Zhytomyr Ivan Franko State University points to a slightly larger amount of disciplines in the normative and selective part of 
science preparation [1]. This volume was 15 credits ( 450 hours), which was $6,25 \%$ of the total number of hours. Compared to the curriculum of National Pedagogical Dragomanov University this is 1,25\% more, however, by 5,05\% less than in Autonomous University of Madrid, by 5,55\% less than at University of Malaga, and by $6,65 \%$ less than at University of Granada.

Science preparation at National University of Ostroh Academy, as well as at Zhytomyr Ivan Franko State University, is 15 credits (450 hours) and is realized only through the study of normative disciplines [5], namely: "Fundamentals of Human Biology and Genetics" (6 credits), "Anthropology" (3 credits), "Zoopsychology and comparative psychology" (3 credits) and "Psychophysiology" (3 credits).

Detailed analysis of training and working programs of future psychologists' preparation in national higher education institutions indicates the absence of both integrative science disciplines and integration of science preparation in the disciplines of professional orientation.

Consequently, results of the research of future psychologists science preparation in leading higher education institutions in Spain and Ukraine indicate a significant difference, both in its lending volume and content.

In accordance with objectives of our study on identifying the directions of modernization of future psychologists science preparation in national higher education institutions using the best examples of Spanish experience in its implementation, we consider it necessary to proceed to experimental work aimed at identifying problems and assessing the current state of science preparation of future psychologists at the search-and-analytic stage of experiment.

180 students of 1-2 years took part in a survey they are studying at 053 specialty Psychology, and 40 teachers.

Taking into account significant difference in credit and content of curricula for future psychologists preparation in 2014-2015 and 2016-2017 academic years, we will analyze results of the questionnaire for students who studied them (pic. 2).

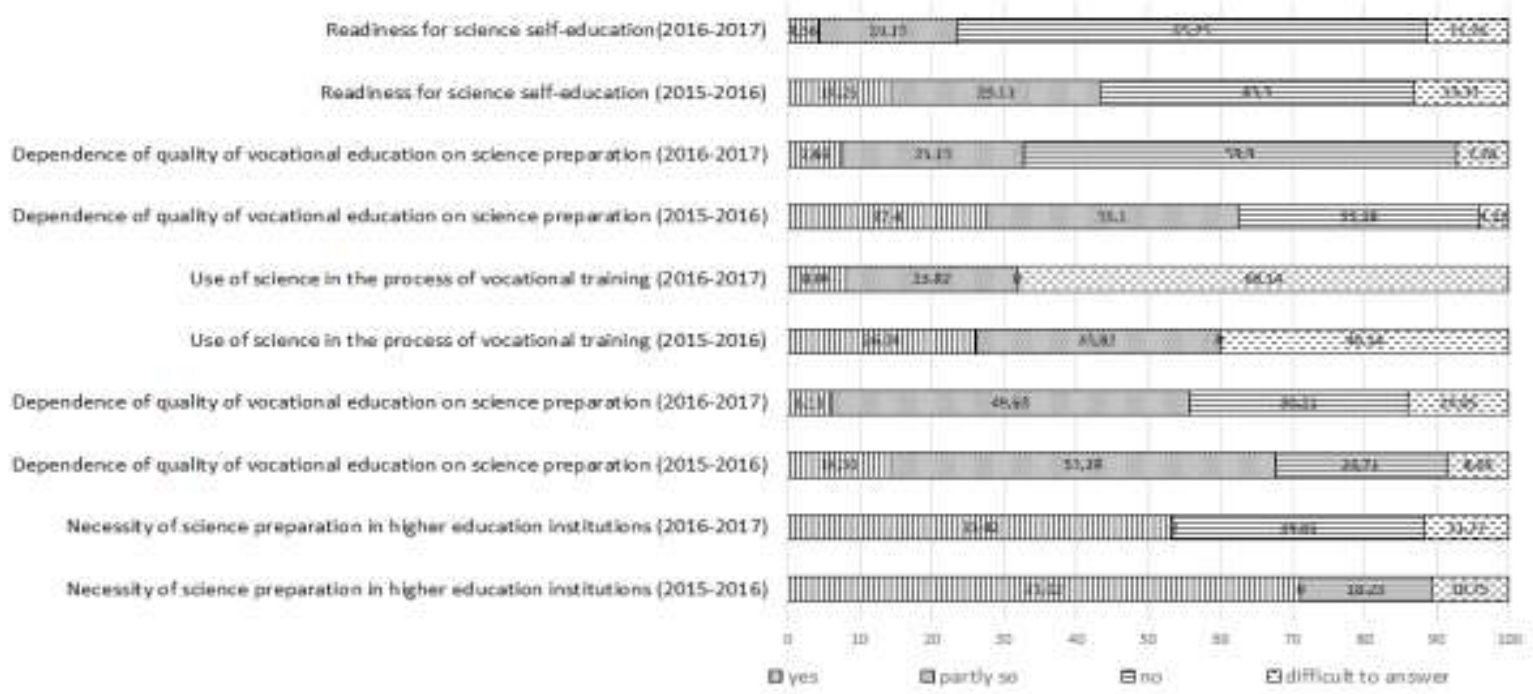

Fig. 2. The current state of science and education of future psychologists (based on student survey results)

Results of future psychologists questionnaire who studied under the curricula of 2014-2015 academic years indicate that $71,02 \%$ of respondents support the need for science education in higher education institutions, but unfortunately $18,23 \%$ do not consider this to be the case it is expedient and $10,75 \%$ has not decided yet, therefore, they chose the answer "difficult to answer".

At the same time, $14,36 \%$ of respondents are regularly interested in literature that could improve their science education, while $53,28 \%$ of students are interested, but not regularly, other respondents $(23,71 \%)$ are not interested in such literature at all. $8,65 \%$ of the students had difficulty answering this question.

Answers of students who studied under curricula of 2016-2017 academic years indicate a decrease in qualitative characteristics of studied indicators, namely: $53,42 \%$ of respondents support the need for science preparation of future psychologists in higher education institutions, $34,81 \%$ do not 
consider it necessary and $11,77 \%$ of students could not decide. $6,11 \%$ of future psychologists are regularly interested in literature that could improve their science education, $49,63 \%$ of the students are interested, but not regularly, other respondents $(30,21 \%)$ are not interested in such literature at all. $14,05 \%$ of the interviewed students had difficulties in answering this question.

Small number of future psychologists who studied under the curricula of 2014-2015 academic years, namely $26,04 \%$ constantly and $33,82 \%$, partially apply the acquired science knowledge while studying professionally oriented disciplines. Remaining students $(40,14 \%)$ did not decide how to answer this question.

Almost the same situation arose with answers of the interviewed students to the question as to whether the quality of their professional preparation depends on the quality of science education. $27,40 \%$ of respondents fully support the idea of such a dependence, partially $-35,10 \%$ of the interviewed students. Unfortunately, answers to this question indicate that $32,28 \%$ of future psychologists do not see a link between professional preparation and quality of science education, $5,22 \%$ of students failed to answer this question.

The rates of students' answers to the question about their readiness for science self-education turned out to be disappointing. In particular, 14,26\% of future psychologists consider themselves fully prepared for science self-education, partly prepared $-29,13 \%$ of interviewed students, $43,3 \%$ of respondents were not prepared for this kind of activity at all, and $13.31 \%$ were not able to answer this question.

Unfortunately, analysis of students responses who studied under the curricula of 2016-2017 academic years, indicates a decrease in quality of studied indicators. Thus, 8,04\% of respondents constantly use acquired science knowledge while studying professionally directed disciplines, $23,82 \%$ of respondents partially use them, the rest of respondents $(68,14 \%)$ have difficulty in answering the question. Fully support the idea of dependence of the quality of professional preparation on the quality of science education $7,69 \%$ of future psychologists, partly $-25,13 \%$ of the interviewed students, $59,9 \%$ of respondents generally do not see connection between professional preparation and quality of science education, $7,28 \%$ of the respondents could not answer this question.

Regarding readiness of the students for science self-education, the answers were distributed as follows: $4,36 \%$ of respondents consider themselves fully prepared, $19,13 \%$ of respondents are partially prepared, $65,25 \%$ of respondents are not prepared for this kind of activity at all, and 11,26\% - could not answer this question

It turned out that main factors that prevents respondents from improving the quality of their science preparation are: lack of professional orientation in science education $(24,74 \%)$, lack of necessary educational and methodological literature $(18,25 \%)$, lack in educational material results of modern scientific researches $(17,01 \%)$, obsolete methods of teaching disciplines $(15,7 \%)$, relevance of the above question $(14,5 \%)$, lack of free time $(9,4 \%)$, other factors $(0,4 \%)$ (pic. 3 ).
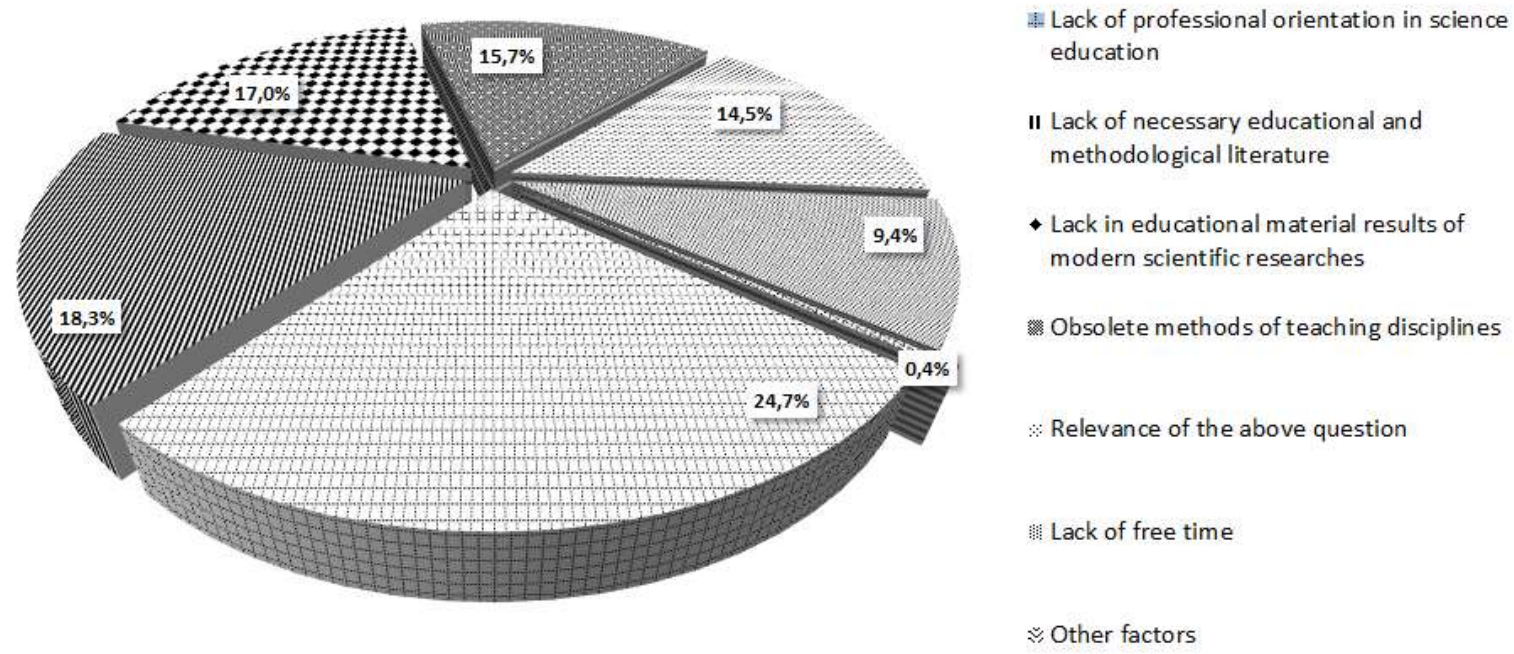

Fig. 3. Factors that prevent future psychologists from improving their science preparation (based on student survey results) 
These student survey data are especially interesting for our study.

The results of questionnaires of 40 university teachers were useful to the research.

Most of teachers $(87,9 \%)$ emphasize the appropriateness of science education of future psychologists, $6,4 \%$ of respondents consider it appropriate, but in a small amount, $3,1 \%$ of the teachers do not see it necessary and 2,6\% of respondents have not decided how to answer.

It is worth pointing out the disappointing results of teacher's acquaintance with foreign experience in the implementation of science preparation of future psychologists. Only a small percentage of respondents $(4,01 \%)$ consider themselves to be sufficiently familiar with the problem, $3,82 \%$ of respondents are partially acquainted, the remaining respondents $(92,17 \%)$ were not familiar with the peculiarities of science preparation in higher education institutions in developed countries.

Among the main factors that reduce effectiveness of science preparation of future psychologists in higher education institutions, teachers mention: lack of necessary motivation for students $(34,28 \%)$, reduction of hours / credits of science preparation in higher educational institutions $(30,01 \%)$, decrease of the number of disciplines of science preparation $(18,1 \%)$ and low level of basic biological education of students $(17,11 \%)$, other factors $(0,5 \%)$ (pic. 4$)$.
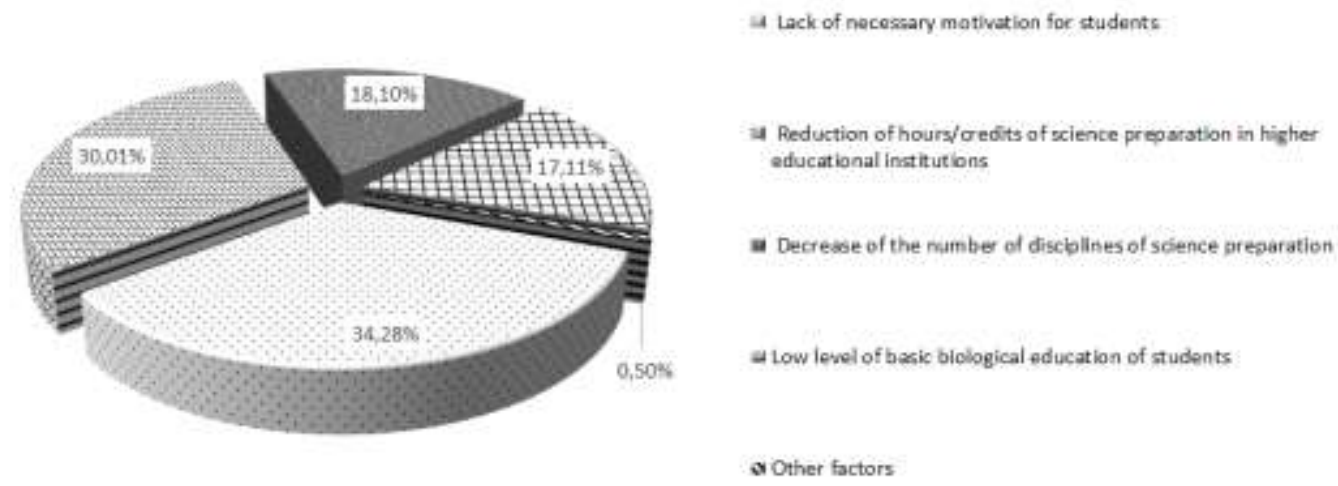

Fig. 4. Factors that reduce effectiveness of science preparation of future psychologists (based on the results of teachers' questionnaire)

Detailed analysis of study results suggests that current state of science education of future psychologists in native higher education institutions can not satisfy neither student's identity nor society or state. The update needs both the content of science education and its methodology.

According to the results of our comparative analysis of science preparation of future psychologists in higher education institutions in Spain and Ukraine and students' and teachers' questioning conducted by us at national universities, directions of science preparation modernization of future psychologists in native higher education institutions are outlined (pic. 5).

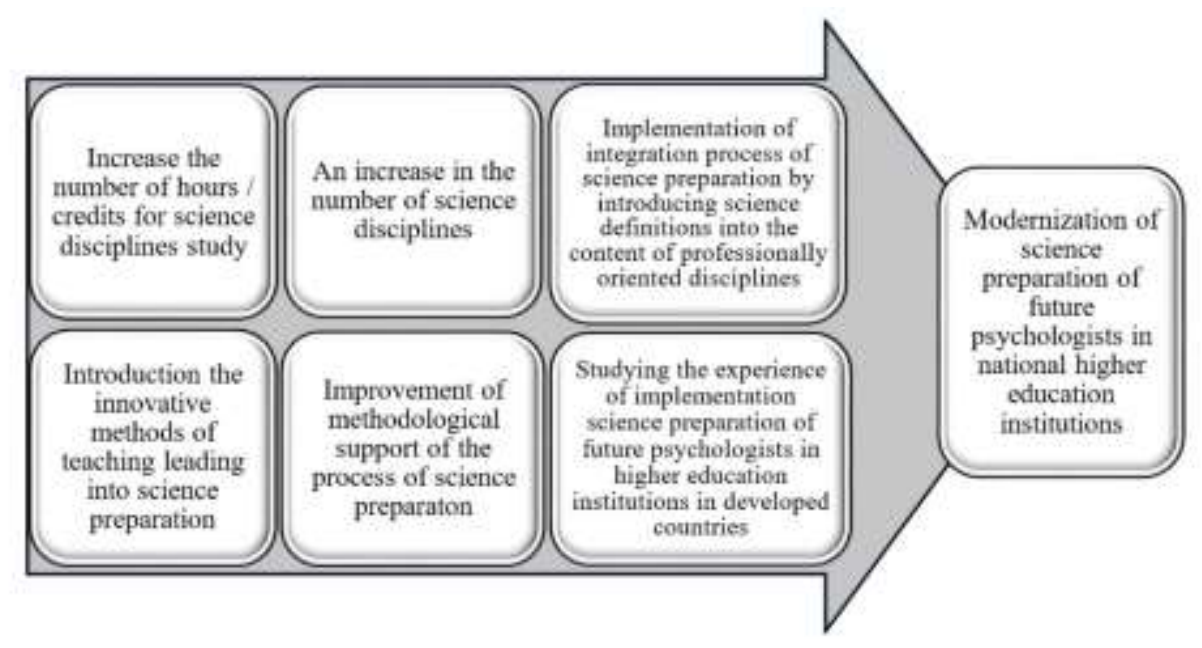

Fig. 5. Directions of science preparation modernization of future psychologists in national higher education institutions 
We believe that modernization of science preparation of future psychologists in native higher education institutions should be carried out in the following areas:

- increase the number of hours/credits for science disciplines study, in order to ensure formation of a fully developed psychologist, creative, capable of innovative activity, self-development and competitiveness in the labor market;

- an increase in the number of science disciplines, aimed at forming an open system of sciences competencies and readiness for effective use of them in professional activity by studentspsychologists;

- implementation of integration process of science preparation by introducing science definitions into the content of professionally oriented disciplines, in order to ensure the integrity of science education and increase students motivation to study the fundamentals of natural sciences;

- introduction of innovative methods of teaching leading scientific theories that will promote the process of science competence formation, a holistic scientific worldview of future psychologists, taking into account their own potential, life experience and needs;

- improvement of methodological support of the process of science preparation in order to overcome possible difficulties in the study of sciences disciplines;

- studying the experience of implementation science preparation of future psychologists in higher education institutions in developed countries (conducting international symposiums, conferences, internships, etc.).

Conclusions. Characteristic differences in science education of Spain from the same in Ukraine, is its professional orientation, integrability and significant advantage in amount of credit and content. It is determined that modernization of science preparation of future psychologists in national higher education institutions is expedient in the direction of: increasing the number of disciplines of science education and hours / credits for their study, implementation of the process of integration science preparation in the content of vocational-oriented disciplines, implementation of innovative teaching methods, leading scientific theories and study of best practices of the developed countries (conducting international symposiums, conferences, internships and etc.).

Presented research provides basis for scientific development of pedagogical conditions for their implementation in national higher education institutions, implementation of identified leading ideas of science education in Spain, and suggests the need to find ways to apply proposed recommendations regarding the modernization of national science education of future psychologists.

\section{REFERENCES}

1. Sayt Zhytomyrs'koho derzhavnoho universytetu im. Ivana Franka [The site of Zhytomyr State University named after. Ivan Franko]. Retrieved from: http://spf.zu.edu.ua/pdf/pp_psihol.pdf. [in Ukrainian]. 06.03.18.

2. Vashchuka F. H. (Ed.) (2011). Intehratsiya $\mathrm{v}$ yevropeys'kyy osvitniy prostir: zdobutky, problemy, perspektyvy: monohrafiya [Integration into the European educational space: achievements, problems, perspectives: monograph]. Series "Eurointegration: Ukrainian Dimension", 16. Uzhhorod: ZakDU. [in Ukrainian].

3. Konobeyeva A. B. (2009). Yestestvennonauchnaya podgotovka studentov v Michurinskom gosudarstvennom pedagogicheskom institute [Natural-scientific preparation of students at the Michurinsk State Pedagogical Institute.]. Issues of modern science and practice. Federal State Unitary Enterprise "Tambov State Technical University", 11(25), 112-115. [in Russian].

4. Kremen' V. (2007). Modernizatsiya systemy vyshchoyi osvity: sotsial'na tsinnist' i vartist' dlya Ukrayiny [Modernization of the system of higher education: social value and cost for Ukraine]. V Kremen' (Eds.). K.: Pedagogical Thought. [in Ukrainian].

5. Sayt Natsional'noho universytetu "Ostroz'ka akademiya" [The site of the National University "Ostroh Academy"]. $\quad$ - $\quad$ Retrieved from: https://www.oa.edu.ua/ua/info/access/public_information_navchanya/navchalni_planu. [in Ukrainian]. 06.03.18.

6. Audisio E. (2011). Aportes de la biología molecular y celular a la formación del psicólogo. III Congreso Internacional de Investigación y Práctica Profesional en Psicología XVIII Jornadas de Investigación Séptimo Encuentro de Investigadores en Psicología del Mercosur. Facultad de Psicología - Universidad de Buenos Aires. (Pp. 101-102). Buenos Aires [in Spanish].

7. Bybee Rodger W. (2011). Scientific Literacy and Student Attitudes: Perspectives from PISA 2006 science. International Journal of Science Education, 33(1), 7-26 [in English].

8. Terradez M., Scaglia R. y Audisio E. (2013). Huella mnémica y huella sináptica: aportes para la vinculación entre psicología y biología. V Congreso Internacional de Investigación y Práctica Profesional en Psicología 
XX Jornadas de Investigación Noveno Encuentro de Investigadores en Psicología del Mercosur. Facultad de Psicología - Universidad de Buenos Aires. (Pp. 227-230). Buenos Aires [in Spanish].

9. Universidad Autónoma de Madrid - Retrieved from: https://www.uam.es/UAM/Facultad-dePsicolog\%C3\%ADa/1242657065836.htm?language=es\&nodepath=Facultad\%20de\%20Psicolog\%C3\%AD a. [in Spanish]. 29.01.18.

10. Universidad de Granada - Retrieved from: http://grados.ugr.es/psicologia/pages/infoacademica/estudios. [in Spanish]. 06.03.18.

11. Universidad de Málaga - Retrieved from: https://www.uma.es/grado-en-psicologia/info/9547/plan-deestudios. [in Spanish]. 26.03.18. 